\title{
New Production and F-ratio on the Continental Shelf of the East China Sea: Comparisons Between Nitrate Inputs From the Subsurface Kuroshio Current and the Changjiang River
}

\author{
Y.-L. Lee Chen ${ }^{a \star}$, H.-B. Lu ${ }^{a}$, F.-K. Shiah ${ }^{b, c}$, G. C. Gong ${ }^{d}$, K.-K. Liu ${ }^{b}$ and \\ J. Kanda ${ }^{e}$ \\ ${ }^{a}$ Department of Marine Resources, National Sun Yat-sen University, Kaohsiung, Taiwan, Republic of China \\ ${ }^{b}$ Institute of Oceanography, National Taiwan University, Taipei, Taiwan, Republic of China ${ }^{c}$ Global Change \\ Research Center, National Taiwan University, Taipei, Taiwan, Republic of China ${ }^{d}$ Department of Oceanography, \\ National Taiwan Ocean University, Keelung, Taiwan, Republic of China ${ }^{e}$ School of Science, Shizuoka University, \\ Shizuoka, fapan
}

Received 28 fuly 1997 and accepted in revised form 20 fuly 1998

\begin{abstract}
This paper reports the first results of the direct measurements of nitrate-based new production and f-ratio on the continental shelf of the East China Sea. The Kuroshio-induced upwelling off north-eastern Taiwan and river runoff from the Changiiang are two principal sources of new nitrogen on the shelf. New production ranged from 70 to $1610 \mathrm{mgC} \mathrm{m}^{-2} \mathrm{~d}^{-1}$, and values of the f-ratio were $0 \cdot 17$ to $0 \cdot 82$. Enhanced new production in the upwelling was significantly related to the ambient nitrate concentration. This implies that the nutrients brought up to the euphotic zone by the intrusion of the subsurface Kuroshio water were quickly reflected by the enhancement of new production. The prediction of f-ratio is feasible in the upwelling region from two ship-measured parameters: light intensity and surface nitrate concentration, but not feasible in the river-influenced shelf waters. New production on the riverine shelf waters, in contrast, was not related to the nitrate input from the Changjiang, but was positively $(P<0 \cdot 05)$ related to water temperature. Low rates of $\mathrm{NO}_{3}{ }^{-}$utilization imply that factors other than nitrate (e.g. phosphate or light) could be the limiting factors determining the new production dynamics in the river mouth.

(C) 1999 Academic Press
\end{abstract}

Keywords: new production; f-ratio; East China Sea; upwelling; Changiiang

\section{Introduction}

Primary production can be partitioned into new production and regenerated production based on the source and form of nitrogen (N) (Dugdale \& Goering, 1967). This has worked well for most oceanic waters because $\mathrm{N}$ is often the most limiting nutrient (Vitousek \& Howarth, 1991). Regenerated production is the part of production dependent upon autochthonous $\mathrm{N}$, mainly ammonium $\left(\mathrm{NH}_{4}{ }^{+}\right)$and urea, derived from the metabolic products of local biological processes. New production is the part of production dependent upon allochthonous $\mathrm{N}$ sources. These sources include nitrate $\left(\mathrm{NO}_{3}{ }^{-}\right)$mixing from deep ocean reserves, $\mathrm{NO}_{3}{ }^{-}$and other $\mathrm{N}$ species transported by river runoff, and atmospheric deposition and biologically fixed $\mathrm{N}$ from the atmosphere. New production is considered to be the fraction of primary production that can be removed from the surface

$\star$ To whom the correspondence should be addressed. mixed layer as fish yields or subpycnocline sedimentation without destroying the long-term integrity of a pelagic ecosystem (Vezina \& Platt, 1987). Therefore, estimation of new production is essential to understand the biogeochemical process or to manage the resource balance of any oceanic ecosystem.

The East China Sea (ECS) is located on a large continental shelf bounded by the Kuroshio Current on the slope side and the coast of China on the other. It is one of the most productive areas of the world oceans. The Changjiang (Yangtze) River, which empties into the ECS at about $31^{\circ} 30^{\prime} \mathrm{N}$ latitude, ranks as the fifth largest river in the world with regard to freshwater discharge $\left(9 \cdot 24 \times 10^{11} \mathrm{~m}^{3}\right.$ year $\left.^{-1}\right)$ and the fourth with regard to solid discharge $\left(4.86 \times 10^{8}\right.$ tons year $^{-1}$ ) (Tian et al., 1993). This discharge clearly provides large nutrient loads to the ECS shelf. Concentrations of $\mathrm{NO}_{3}{ }^{-}$, silicate and phosphate in the Changjiang were reported to be as high as $32 \cdot 9,95$ and $0.57 \mu \mathrm{M}$, respectively (Zhang, 1996). A net 
oceanic flux of $\mathrm{NO}_{3}{ }^{-}$was estimated to be as much as $60 \times 10^{9} \mathrm{~mol} \mathrm{year}^{-1}$ (Edmond et al., 1985). Off north-eastern Taiwan, at the southern part of the ECS, a permanent upwelling occurs when the Kuroshio Current intrudes onto the continental shelf (Chern et al., 1990). Nutrients, including nitrate, phosphate and silicate (Wong et al., 1991), contained within subsurface Kuroshio water are brought up to the euphotic zone at the shelf break around $25^{\circ} 20^{\prime} \mathrm{N}$ latitude. High phytoplankton biomass (Chen, 1992; 1994; 1995a) and primary productivity (Chen, 1995b) were reported.

The new production regime in the Changjiang estuary is likely to be far more complicated than the simple model depicted by Dugdale and Goering (1967). In their original model, nitrate from depth is the only new nitrogen source considered. Non-nitrate new nitrogen such as ammonium $\left(\mathrm{NH}_{4}{ }^{+}\right)$or organic $\mathrm{N}$ are supplied in significant quantities by the Changjiang river. Unlike what is observed in most oceanic environments, phosphate, not $\mathrm{N}$, limits primary production near the river mouth due to high $\mathrm{N} / \mathrm{P}$ in the river inflow (Harrison et al., 1990), and this potentially means another definition of new production based on phosphate is required.

Although it has been well recognized that both the Changjiang river runoff and the Kuroshio upwelling are two principal sources of new $\mathrm{N}$, it is still unclear how these $\mathrm{N}$ inputs affect the primary production and f-ratio of the ECS. The purpose of this study was to elucidate and to compare the controlling mechanisms of new production in the upwelling and the riverine shelf water regions. The authors focussed their analysis on nitrate-based production, which is likely to be the dominant portion of new production, and then compared it with the available estimates of other new $\mathrm{N}$ sources. Regression models also were developed to predict the nitrate-based new production in these waters.

\section{Methods}

Experiments and sampling were carried out in two water regions. The upwelling region was studied during three cruises: OR1-416 (April 15-22, 1995), OR2-124 (June 10-14, 1995) and OR1-431 (September 27-October 3, 1995), covering the same transect (stations 1-17, Figure 1). The continental shelf region influenced by runoff of the Changiiang River was studied during Cruise OR1-449 (May 2-15, 1996; stations E1-E7).

For hydrographic observations, a rosette multisampler with attached CTD probes (Seabird SBE
9/11) was used, and water samples were collected from 3, 10, 25, 50, 75 and $100 \mathrm{~m}$. Surface water $(0 \mathrm{~m})$ was collected with a bucket. Water samples were filtered onboard ship using Whatman GF/F glass-fiber filters under low vacuum $(<100 \mathrm{mmHg})$. The filter samples were kept in darkness and frozen at $-20{ }^{\circ} \mathrm{C}$ until analysis. Chlorophyll $a$ concentration was determined on extracted filtrate in $90 \%$ acetone for $20 \mathrm{~h}$ (Strickland \& Parsons, 1972) using a fluorescence spectrophotometer (F3000, Hitachi Co., Tokyo, Japan). The mean of two replicates is reported below for all observations. Nitrate and phosphate concentrations were analysed by standard spectrophotometric methods (Strickland \& Parsons, 1972). Surface and underwater light intensities were measured either by a quantum meter (Li-188B, Li-Cor Inc., U.S.A.) or a PAR sensor (OSP200L, Biospherical Inc., U.S.A.). The depth of the euphotic zone was defined as $0.6 \%$ of the surface light penetration. The depth of mixed layer $\left(Z_{m}\right)$ was defined as the depth where the density $(\sigma \theta)$ gradient exceeded $0 \cdot 1 \mathrm{~m}^{-1}$.

Primary production and new production measurements were conducted at selected stations (3 to 7 stations) during each cruise (Table 1 ). All the production stations were located on the continental shelf with water depth less than $200 \mathrm{~m}$.

During the upwelling cruises, water for measurement of photosynthetic production was collected by $20-\mathrm{L}$ Go-Flo bottles from the surface $(100 \%$ light intensity) and from the light penetration depths (LPD) equivalent to $46,38,13,2$ or $0.6 \%$ of the surface irradiance. The water was immediately transferred into $2 \cdot 3-\mathrm{L}$ transparent polycarbonate bottles at LPD equivalents of $100,46,38,13,2$ or $0.6 \%$ using neutral density screens. Two light bottles and one dark bottle were incubated at each LPD. The dark bottle was covered with four layers of black plastic sheets to ensure total darkness. The bottles were incubated on deck in transparent water tanks with flow-through of in situ surface seawater under natural light for $24 \mathrm{~h}$. Before incubation, $\mathrm{NaH}^{13} \mathrm{CO}_{3}$ (99 atom \%, Isotec, Ohio, U.S.A.) was added to the primary production bottles so that the final concentration was $0 \cdot 19 \mathrm{mM}$; $\mathrm{Na}^{15} \mathrm{NO}_{3}$ was added to the new production bottles at a concentration equivalent to $10 \%$ of ambient $\mathrm{NO}_{3}{ }^{-}$ concentration. The initial and the incubated water were filtered through precombusted $\left(450{ }^{\circ} \mathrm{C}, 4 \mathrm{~h}\right.$ glass fiber filters (Whatman $\mathrm{GF} / \mathrm{F}$ ). The filter papers were then treated with $\mathrm{HCl}$ fumes for $2 \mathrm{~h}$ to remove carbonate and were completely dried in a vacuum desiccator. Particulate organic carbon, particulate nitrogen and the isotopic ratios of ${ }^{13} \mathrm{C} /{ }^{12} \mathrm{C}$ and ${ }^{15} \mathrm{~N} /{ }^{14} \mathrm{~N}$ were determined by a mass spectrometer (ANCA-MASS 20-20, Europa Scientific Ltd., Crewe, U.K.). Measurement 


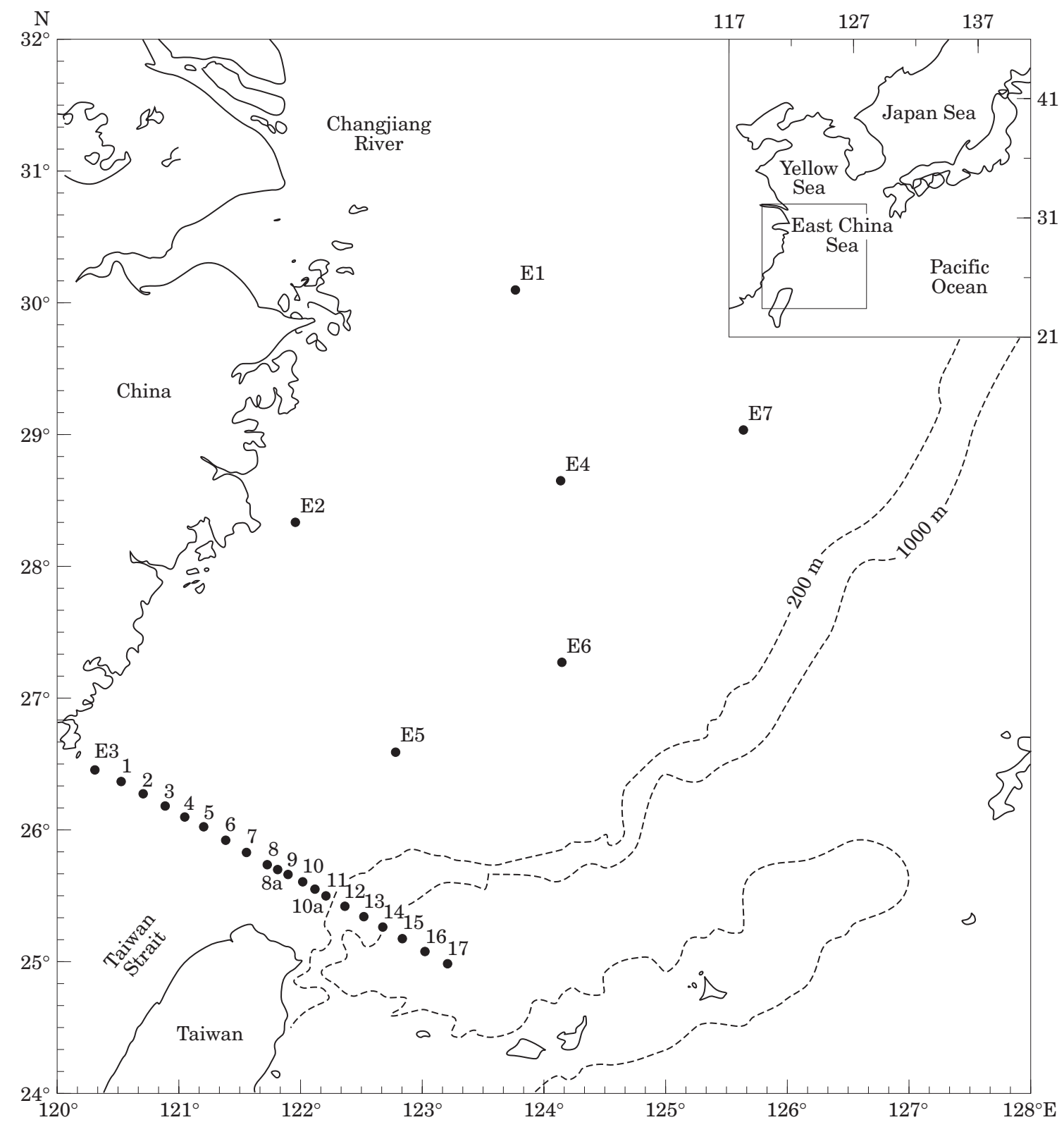

Figure 1. Sampling stations on the East China Sea and the Kuroshio. The transect among stations 1 to 17 were sampled during cruise 416, 124 and 431; Stations E1 to E7 were sampled during cruise 449.

of ${ }^{13} \mathrm{C}$ atom $\%$ and ${ }^{15} \mathrm{~N}$ atom $\%$ were reproducible at a precision of \pm 0.0002 and $0.0003 \%$, respectively. Concentration of total inorganic carbon was determined from alkalinity (Strickland \& Parsons, 1972).

Primary production measurements in the Changjiang riverine shelf water was carried out by the ${ }^{14} \mathrm{C}$ assimilation method (Parsons et al., 1984). Water samples were taken before dawn. Three light and one dark $250 \mathrm{ml}$ polycarbonate bottles were filled with water and inoculated with $\mathrm{NaH}^{14} \mathrm{CO}_{3}$ (final concentrations $10 \mu \mathrm{Ci} \mathrm{ml}^{-1}$ ). One light bottle was filtered immediately as the time-zero sample. Two light and one dark bottles for each depth were tethered onto an in situ array. The array was anchored with a $30-50 \mathrm{~kg}$ weight at the bottom to position the samples at their original depths. Following retrieval of bottles after $4-5 \mathrm{~h}$ of incubation (from about 8:00 to noon), the water sample in each bottle was filtered through a Whatman $25 \mathrm{~mm} \mathrm{GF} / \mathrm{F}$ filter. The filters were then placed in scintillation vials with $0.5 \mathrm{ml}$ of $0.5 \mathrm{~N} \mathrm{HCl}$ to remove residual $\mathrm{H}^{14} \mathrm{CO}_{3}{ }^{-}$. Radioactivity in each vial was measured in a liquid scintillation counter (Packard 1600) after addition of $10 \mathrm{ml}$ scintillation 
TABLE 1. Location, bottom depth, depth of euphotic zone $(0.6 \%$ of the surface light intensity) and the depth of mixed layer $\left(Z_{\mathrm{m}}\right.$, difference of $\sigma \theta$ value $\left.<0 \cdot 1 \mathrm{~m}^{-1}\right)$ of the sampling stations where new production and primary production were measured during various cruises

\begin{tabular}{|c|c|c|c|c|c|c|}
\hline \multirow{2}{*}{$\begin{array}{l}\text { Cruise } \\
\text { (date) }\end{array}$} & \multirow[b]{2}{*}{ Station } & \multicolumn{2}{|c|}{ Location } & \multirow{2}{*}{$\begin{array}{l}\text { Bottom } \\
\text { depth } \\
\text { (m) }\end{array}$} & \multirow{2}{*}{$\begin{array}{l}\text { Euphotic } \\
\text { layer depth } \\
\text { (m) }\end{array}$} & \multirow{2}{*}{$\begin{array}{l}Z_{\mathrm{m}} \\
(\mathrm{m})\end{array}$} \\
\hline & & Longitude (E) & Latitude $(\mathrm{N})$ & & & \\
\hline \multirow[t]{3}{*}{416 (15-22 April 1995) } & 5 & $121^{\circ} 10^{\prime}$ & $26^{\circ} 00^{\prime}$ & 85 & 42 & $>76$ \\
\hline & 9 & $121^{\circ} 50^{\prime}$ & $25^{\circ} 40^{\prime}$ & 125 & 54 & $>102$ \\
\hline & 11 & $122^{\circ} 10^{\prime}$ & $25^{\circ} 30^{\prime}$ & 145 & 84 & 70 \\
\hline \multirow[t]{5}{*}{124 (10-14 June 1995) } & 8 & $121^{\circ} 40^{\prime}$ & $25^{\circ} 44^{\prime}$ & 117 & 68 & 77 \\
\hline & $8 a$ & $121^{\circ} 44^{\prime}$ & $25^{\circ} 45^{\prime}$ & 123 & 73 & 70 \\
\hline & 9 & $121^{\circ} 50^{\prime}$ & $25^{\circ} 40^{\prime}$ & 126 & 73 & 53 \\
\hline & 10 & $122^{\circ} 00^{\prime}$ & $25^{\circ} 35^{\prime}$ & 118 & 30 & $>100$ \\
\hline & $10 \mathrm{a}$ & $122^{\circ} 05^{\prime}$ & $25^{\circ} 30^{\prime}$ & 136 & 40 & 3 \\
\hline \multirow{4}{*}{$\begin{array}{l}431 \text { (27 September- } \\
3 \text { October 1995) }\end{array}$} & & & & & & \\
\hline & 9 & $121^{\circ} 50^{\prime}$ & $25^{\circ} 40^{\prime}$ & 122 & 68 & 54 \\
\hline & 10 & $122^{\circ} 00^{\prime}$ & $25^{\circ} 35^{\prime}$ & 116 & 79 & 38 \\
\hline & 11 & $122^{\circ} 10^{\prime}$ & $25^{\circ} 30^{\prime}$ & 123 & 84 & $>102$ \\
\hline \multirow{7}{*}{449 (2-15 May 1996) } & E1 & $123^{\circ} 48^{\prime}$ & $30^{\circ} 07^{\prime}$ & 60 & 36 & 10 \\
\hline & $\mathrm{E} 2$ & $121^{\circ} 59^{\prime}$ & $28^{\circ} 20^{\prime}$ & 50 & 29 & 10 \\
\hline & E3 & $120^{\circ} 16^{\prime}$ & $26^{\circ} 28^{\prime}$ & 45 & 38 & 5 \\
\hline & $\mathrm{E} 4$ & $124^{\circ} 08^{\prime}$ & $28^{\circ} 38^{\prime}$ & 80 & 27 & 40 \\
\hline & E5 & $122^{\circ} 46^{\prime}$ & $26^{\circ} 35^{\prime}$ & 106 & 55 & 20 \\
\hline & E6 & $124^{\circ} 08^{\prime}$ & $27^{\circ} 16^{\prime}$ & 100 & 71 & 30 \\
\hline & E7 & $125^{\circ} 37^{\prime}$ & $29^{\circ} 02^{\prime}$ & 100 & 66 & 60 \\
\hline
\end{tabular}

cocktail (Ultima Gold, Packard). Nitrate uptake measurements were carried out concurrently with primary production by inoculating ${ }^{15} \mathrm{NO}_{3}$ in two 1.01 polycarbonate bottles and incubating in situ for 4$5 \mathrm{~h} .{ }^{15} \mathrm{NO}_{3}$ assimilated was determined by a mass spectrometer (VG Micro Mass 622). The uptake measured during the morning hours was multiplied by a factor of approximately three to obtain the daily assimilation rate in accordance with the local diel cycle which was previously established (unpublished results). Particulate organic nitrogen concentration was measured by a CHN analyser (Carlo-Erba EA 1400) connected to the mass spectrometer.

Two incubation schemes were used in the present study. The $24 \mathrm{~h}$ incubation for the upwelling area could possibly lead to underestimation of nitrate uptake because of isotope depletion during prolonged incubations. Turnover times for the observed $\mathrm{NO}_{3}$ (observed $\mathrm{NO}_{3}$ concentration/ $\mathrm{NO}_{3}$ uptake rate) on the two upper incubation depths in the upwelling region were mostly in the range of $<0 \cdot 8-1 \cdot 9$ day. This implies that the nitrate uptake rates are probably underestimated due to substrate exhaustion. The incubation in the riverine shelf water was, by comparison, short. Underestimation of rates in riverine shelf waters was unlikely and even if underestimation were to occur this would pose no problem in our conclusion since it could occur only in the upwelling region where nitrate uptake rates were high. In contrast, low uptake rates were observed at the Changjiang riverine shelf region. These low uptake values could not have resulted from underestimation because the incubation time was relatively short.

Primary production was calculated (Hama et al., 1983) from the uptake rate of ${ }^{13} \mathrm{C}$ or ${ }^{14} \mathrm{C}$. Hama et al. (1983) reported excellent agreement between the ${ }^{14} \mathrm{C}$ and ${ }^{13} \mathrm{C}$ methods. Nitrate assimilation rate was calculated following the equations (2) and (3) of Dugdale and Wilkerson (1986). From the nitrate assimilation rate and the Redfield ratio $(\mathrm{C}: \mathrm{N}=6 \cdot 6)$, nitrate-based new production in unit of carbon was then obtained (Dugdale et al., 1989). f-Ratio was calculated as new production divided by primary production. Water column integrated production per $\mathrm{m}^{2}$ was calculated by trapezoidal integration from 100 to $0.6 \mathrm{LPD}$ to provide daily integrated primary production (IPP) and daily integrated new production (INP) per $\mathrm{m}^{2}$.

A step-wise multiple regression analysis procedure (Draper \& Smith, 1981) was used to examine the spatial relationships of nitrate-based new production, primary production, $\mathrm{NO}_{3}{ }^{-}$concentration, water temperature and chlorophyll a concentration. The relationships between chlorophyll normalized uptake rates and light intensity were fitted with Michaelis-Menten equations by SigmaPlot. 

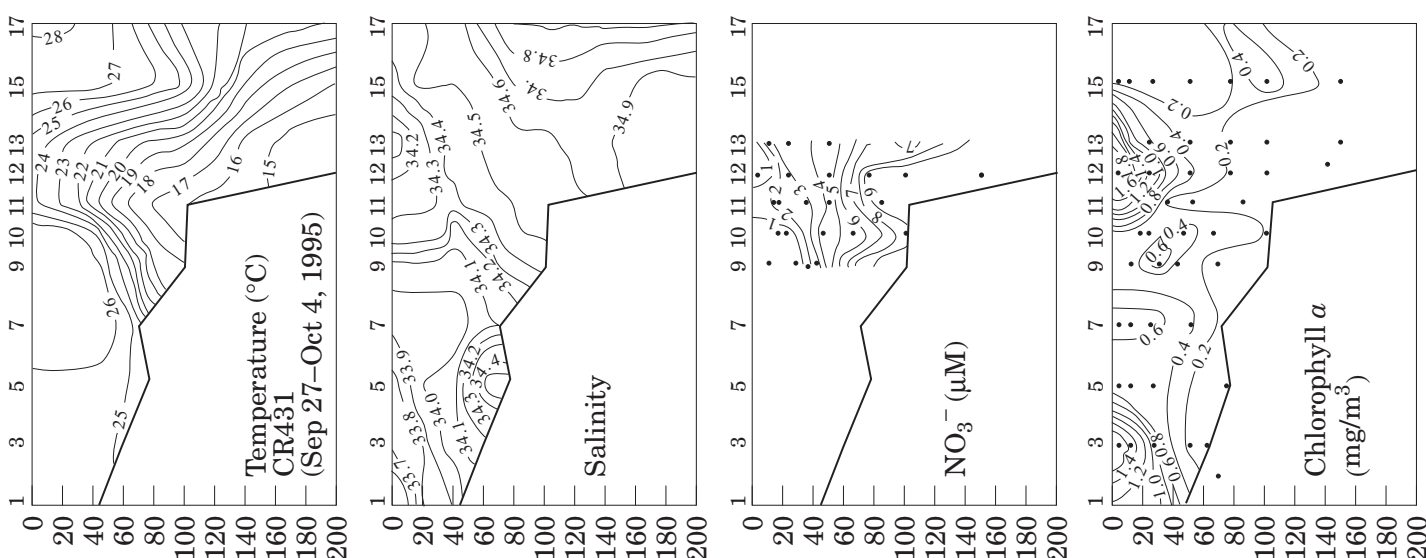

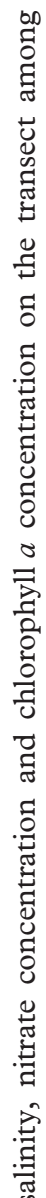
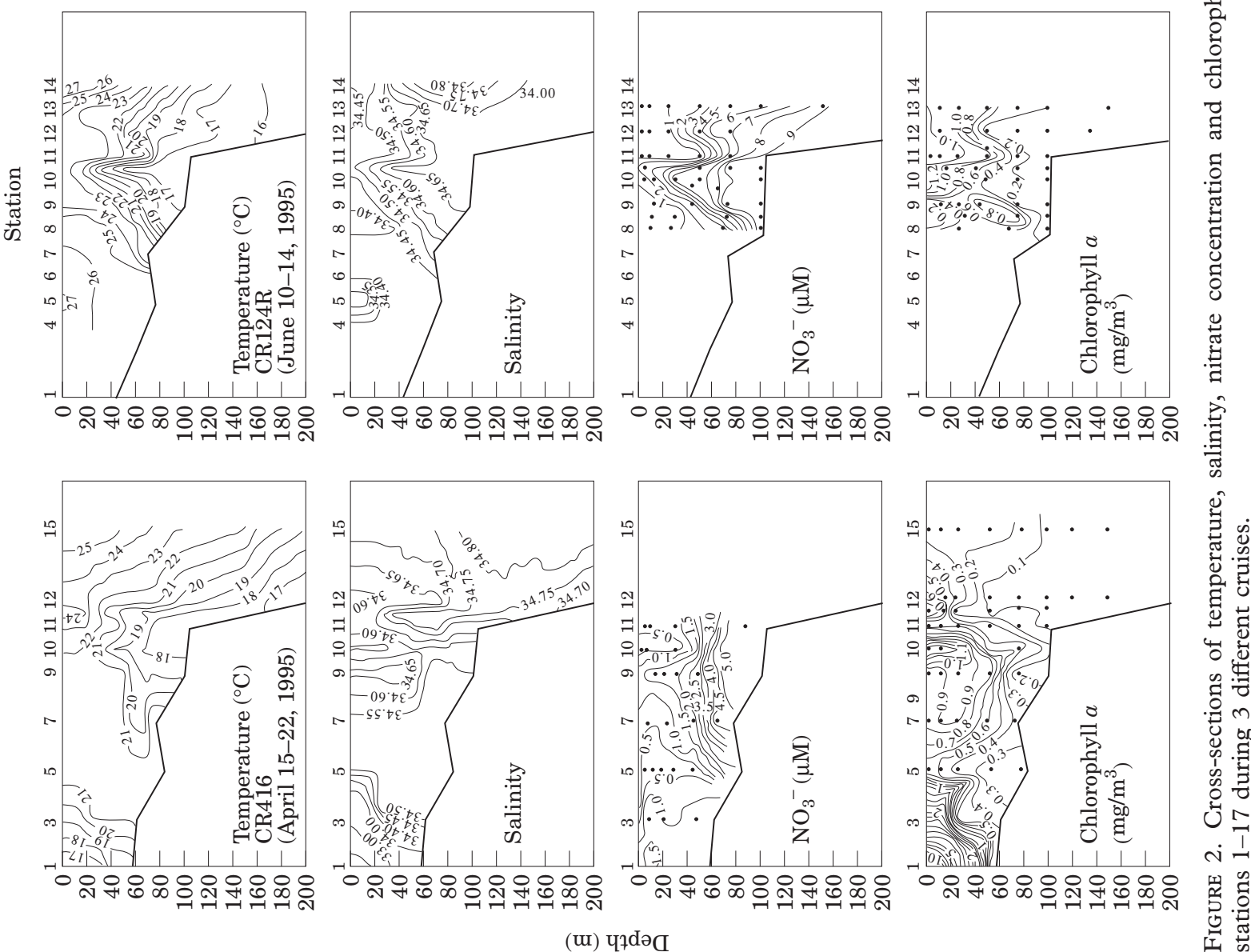

(ய) чұdәС 

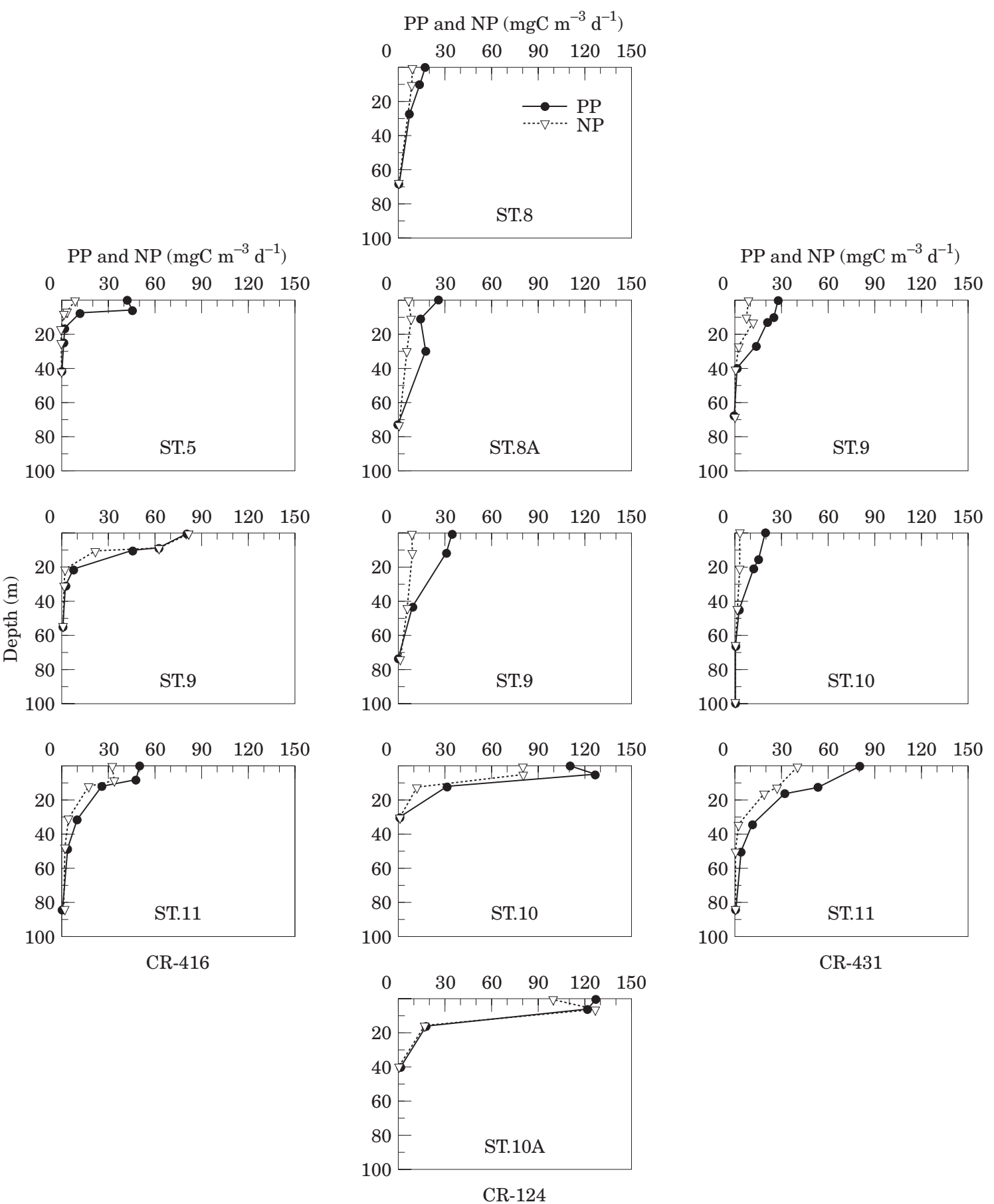

FIGURE 3. Vertical distribution of primary production (PP) and nitrate-based new production (NP) measured during three different cruises.

\section{Results}

\section{The upwelling region}

The plume centre of the upwelling at the shelf break could be easily located by hydrography. At the plume centre, the surface water was lower in temperature and higher in salinity, nitrate, and chlorophyll $a$ concentration than the adjacent waters (Figure 2). Although the plume centre shifted slightly from cruise to cruise, it always appeared near the shelf break. These upwelling characteristics were observed repeatedly for all cruises and confirm the persistence of the 

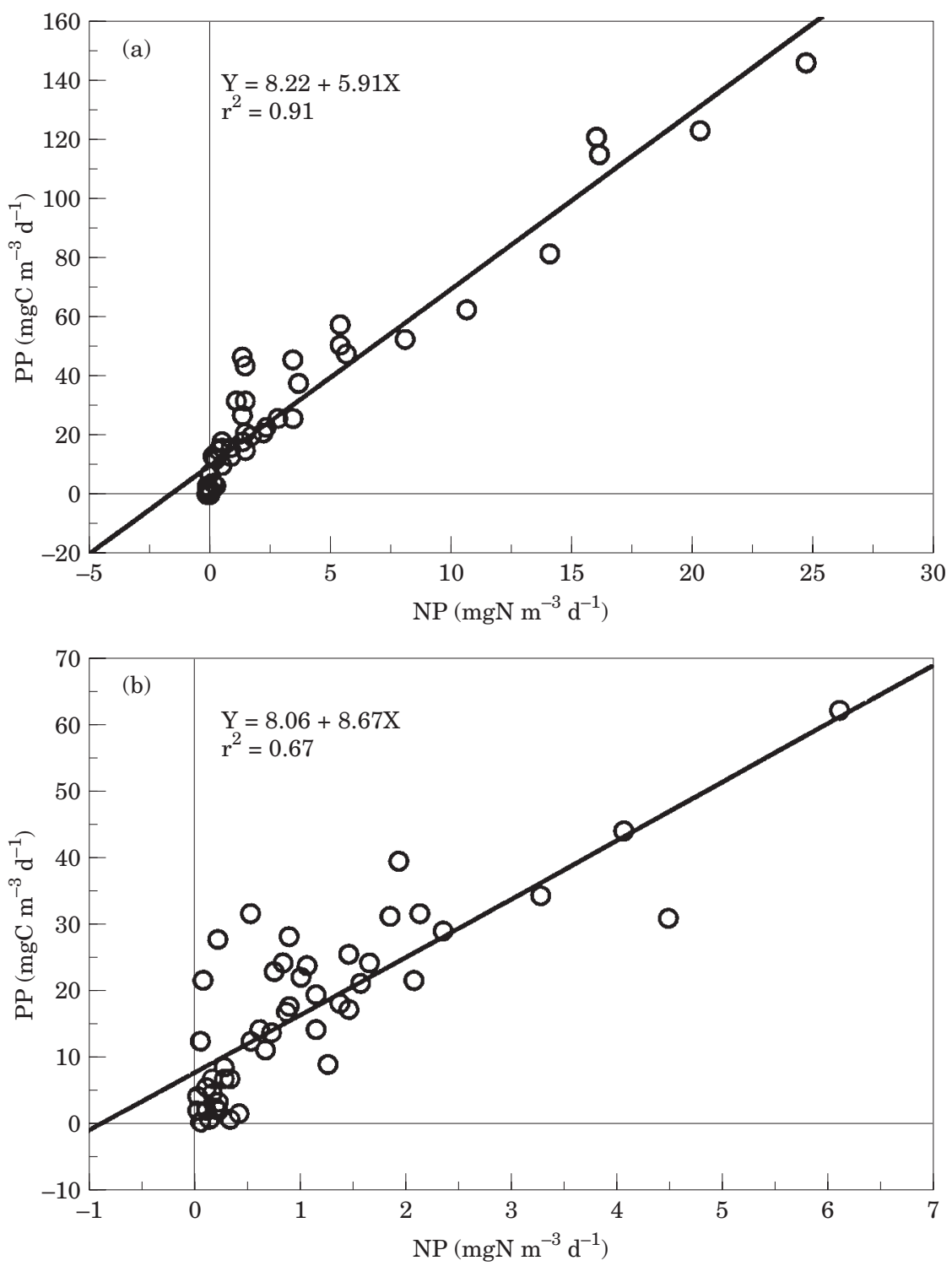

FIGURE 4. Relationship between primary production (PP) and nitrate-based new production (NP) in (a) the upwelling region and the (b) Changjiang riverine shelf region respectively.

upwelling (Chern et al., 1990). Surface nitrate concentrations as high as $2 \mu \mathrm{M}$ were observed at the location where lowest surface water temperature was measured (Figure 2). This high nitrate concentration resulted in a high chlorophyll $a$ concentration in the euphotic zone (Figure 2). Shelf waters between Stations 1 and 3 near the coast of China, with the distinctive characteristic of low salinity, were also high in chlorophyll $a$ concentrations.

Depth profiles of primary and nitrate-based new production in the shelf break and the adjacent shelf waters showed high values in the surface layer and decreased with depth (Figure 3). This suggests that light is possibly more important than nitrate in deter- mining the vertical profile of production even though nitrate is usually considered a significant factor in controlling primary or new production in these subtropical waters. Vertical distributions of primary production (PP) and nitrate-based new production (NP) were also related significantly $(P<0.01)$ to in situ chlorophyll a concentration. Waters with higher chlorophyll a concentration ([Chl], $\mathrm{mg} \mathrm{m}^{-3}$ ) and average light intensity at the depth of incubation (Light, $\mu \mathrm{E} \mathrm{m}^{-2} \mathrm{~s}^{-1}$ ), i.e. shallower waters, showed a higher primary or new production than those of lowchlorophyll deep water. Correlation between PP and $\mathrm{NP}$ was also quite high $(\mathrm{r}=0 \cdot 95$, Figure 4$)$. Multiple regression analysis depicted their relationships as: 
TABle 2. Parameters of Michaelis-Menten equations describing the relationships between average light intensity ( $\mathrm{L}, \mu \mathrm{E} \mathrm{m} \mathrm{m}^{-2} \mathrm{~s}^{-1}$ ) during the incubation for various depths and nitrate uptake rate ( $\rho \mathrm{NO} 3 / \mathrm{Chl}$, mg at-N mg Chl ${ }^{-1} \mathrm{day}^{-1}$ ) or carbon uptake rate $\left(\rho \mathrm{C} / \mathrm{Chl}\right.$, $\mathrm{mg}$ at-C $\mathrm{mg} \mathrm{Chl}^{-1} \mathrm{day}^{-1}$ ). The equation fitted is $\rho_{\max } \cdot \mathrm{L} /\left(\mathrm{K}_{\mathrm{L}}+\mathrm{L}\right)$ where $\rho_{\max }$ and $\mathrm{K}_{\mathrm{L}}$ are the parameters

\begin{tabular}{|c|c|c|c|c|c|c|c|}
\hline \multirow{2}{*}{$\begin{array}{l}\text { Cruise/ } \\
\text { station }\end{array}$} & \multicolumn{3}{|c|}{$\rho \mathrm{NO} 3 / \mathrm{Chl}$} & \multicolumn{3}{|c|}{$\rho \mathrm{C} / \mathrm{Chl}$} & \multirow{2}{*}{$\begin{array}{l}\text { Average surface } \\
\text { light intensity }\end{array}$} \\
\hline & $\rho_{\max }$ & $\mathrm{K}_{\mathrm{L}}$ & $\mathrm{R}^{2}$ & $\rho_{\max }$ & $\mathrm{K}_{\mathrm{L}}$ & $\mathrm{R}^{2}$ & \\
\hline \multicolumn{8}{|c|}{ Cruise 416} \\
\hline St. 5 & & - & & & - & & $343^{\star}$ \\
\hline St. 9 & & - & & $20 \cdot 94$ & 1469 & 0.92 & $1322^{\star}$ \\
\hline St. 11 & $2 \cdot 00$ & 1328 & $0 \cdot 89$ & $21 \cdot 34$ & 1466 & $0 \cdot 94$ & $1327^{\star}$ \\
\hline \multicolumn{8}{|c|}{ Cruise 124} \\
\hline St. 8 & $0 \cdot 45$ & $225 \cdot 6$ & 0.99 & $9 \cdot 65$ & $635 \cdot 4$ & 0.99 & $563^{\star}$ \\
\hline St. $8 \mathrm{a}$ & & - & & $7 \cdot 02$ & $80 \cdot 43$ & 0.96 & $747^{\star}$ \\
\hline St. 9 & $0 \cdot 29$ & $180 \cdot 5$ & $0 \cdot 83$ & $10 \cdot 1$ & $398 \cdot 1$ & $0 \cdot 84$ & $923^{\star}$ \\
\hline St. 10 & $1 \cdot 61$ & 1029 & $0 \cdot 97$ & $16 \cdot 0$ & $831 \cdot 9$ & 0.99 & $1232^{\star}$ \\
\hline St. $10 \mathrm{a}$ & $1 \cdot 74$ & $270 \cdot 1$ & $0 \cdot 83$ & $5 \cdot 8$ & $451 \cdot 5$ & $0 \cdot 94$ & $826^{\star}$ \\
\hline \multicolumn{8}{|c|}{ Cruise 431} \\
\hline St. 9 & $0 \cdot 45$ & $302 \cdot 4$ & $0 \cdot 74$ & $10 \cdot 3$ & $455 \cdot 5$ & 0.97 & $1068^{\star}$ \\
\hline St. 10 & $0 \cdot 13$ & $100 \cdot 7$ & $0 \cdot 90$ & $8 \cdot 09$ & $329 \cdot 4$ & 0.92 & $472^{\star}$ \\
\hline St. 11 & 0.52 & $497 \cdot 1$ & $0 \cdot 98$ & $4 \cdot 72$ & $72 \cdot 29$ & $0 \cdot 85$ & $1277^{\star}$ \\
\hline \multicolumn{8}{|c|}{ Cruise 449} \\
\hline St. E1 & $0 \cdot 21$ & $115 \cdot 8$ & $0 \cdot 72$ & & - & & $644 \dagger$ \\
\hline St. E2 & & - & & $3 \cdot 26$ & $111 \cdot 8$ & 0.97 & $968+$ \\
\hline St. E3 & $0 \cdot 71$ & $549 \cdot 1$ & $0 \cdot 85$ & $4 \cdot 69$ & $97 \cdot 95$ & $0 \cdot 76$ & $1018+$ \\
\hline St. E4 & $0 \cdot 37$ & $220 \cdot 9$ & 0.97 & $2 \cdot 66$ & $56 \cdot 21$ & $0 \cdot 98$ & $226 \dagger$ \\
\hline St. E5 & & - & & $3 \cdot 34$ & $159 \cdot 1$ & 0.93 & $579 \dagger$ \\
\hline St. E6 & & - & & $5 \cdot 09$ & $56 \cdot 41$ & $0 \cdot 87$ & $773 \dagger$ \\
\hline St. E7 & & - & & $4 \cdot 46$ & $90 \cdot 55$ & $0 \cdot 91$ & $1065 t$ \\
\hline
\end{tabular}

$\mathrm{PP}=-15 \cdot 39+56 \cdot 24[\mathrm{Chl}]+0 \cdot 038 \mathrm{Light}\left(\mathrm{R}^{2}=0 \cdot 59\right)$; $\mathrm{NP}=-19 \cdot 36+55 \cdot 29[\mathrm{Chl}]+0 \cdot 023 \mathrm{Light}\left(\mathrm{R}^{2}=0 \cdot 54\right)$

The Michaelis-Menten equation was able to describe the relationships between chlorophyll normalized uptake rates and average light intensity during the incubation for each light depth at most of the stations (Table 2). Results of two representative stations are shown in Figure 5.

Primary production and new production were higher in shelf break waters than in adjacent waters. At the shelf break, primary production was usually $>1 \mathrm{gC} \mathrm{m}^{-2}$ day $^{-1}$ with a maximum value of $1.96 \mathrm{gC} \mathrm{m}^{-2}$ day $^{-1}$ (Table 3). In contrast, primary production in the non-upwelling shelf water ranged from $0.43 \mathrm{gC} \mathrm{m}^{-2}$ day $^{-1}$ at Station 5 to $0.88 \mathrm{gC} \mathrm{m}^{-2}$ day $^{-1}$ at Station $8 \mathrm{a}$. New production for all stations ranged between 0.08 and $1.61 \mathrm{gC} \mathrm{m}^{-2}$ day $^{-1}$ (Table 3). New production was generally high near the shelf break; while low values were observed at the mid-shelf stations (Stations 5, 8 and $8 \mathrm{a}$ ). However, low new production was observed at some stations near the shelf break. For example, new production at Stations 9 and 10 during cruise 431 were 0.27 and $0.14 \mathrm{gC} \mathrm{m}^{-2}$ day $^{-1}$, respectively. Integrated new production (INP) was positively correlated with integrated primary production (IPP) and surface nitrate concentration $\left(\mathrm{NO}_{3}\right.$-surf) (Table 4$)$. The chlorophyll normalized new production (INP/ IChl, integrated new production/integrated chlorophyll $a, \mathrm{mgC} \mathrm{mgChl}^{-1} \mathrm{day}^{-1}$ ) was also significantly and positively correlated to chlorophyll normalized primary production (IPP/IChl) and the surface nitrate concentration (Table 4). The combined regression equation is:

$$
\begin{aligned}
\mathrm{INP} / \mathrm{IChl}= & -0.9801+0 \cdot 693 \mathrm{IPP} / \mathrm{IChl}+6 \cdot 31 \\
& \mathrm{NO}_{3}-\operatorname{surf}\left(\mathrm{R}^{2}=0 \cdot 89\right)
\end{aligned}
$$

Integrated f-ratio (INP/IPP) was significantly related to the average on-deck light intensity during incubation (Light, $\mu \mathrm{E} \mathrm{m}^{-2} \mathrm{~s}^{-1}$ ) and the surface nitrate concentration (Table 4). The combined equation is:

$$
\begin{aligned}
\mathrm{f}-\text { Ratio }= & 0 \cdot 127+0 \cdot 0002427 \text { Light }+0 \cdot 176 \\
& \mathrm{NO}_{3} \text {-surf }\left(\mathrm{R}^{2}=0 \cdot 72\right)
\end{aligned}
$$



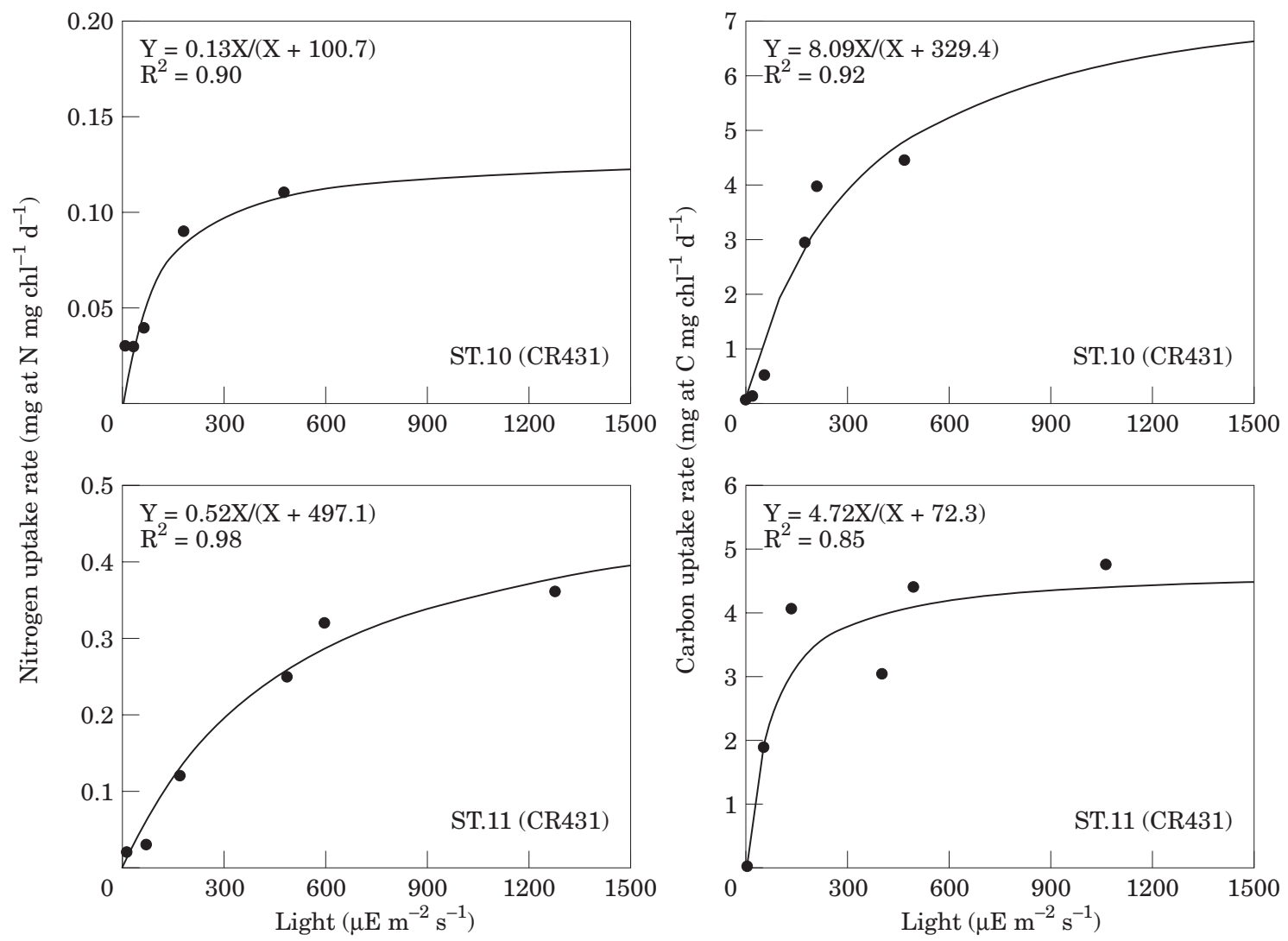

Figure 5. Effects of the average light intensity $\left(\mu \mathrm{E} \mathrm{m}^{-2} \mathrm{~s}^{-1}\right)$ during the incubation on nitrate $\left(\mathrm{mg} \mathrm{at}^{-\mathrm{N} \mathrm{mg} \mathrm{Chl}} \mathrm{m}^{-1} \mathrm{day}^{-1}\right)$ and carbon uptake rate ( $\mathrm{mg}$ at-C $\mathrm{mg} \mathrm{Chl}^{-1} \mathrm{day}^{-1}$ ) at respective light depth in Station 10 (a shelf station) and Station 11 (an upwelling station) investigated during cruise 431 .

Thus the prediction of f-ratio in this region is feasible from ship-measured parameters which are often readily available.

\section{The Changjiang riverine shelf region}

Primary production and nitrate-based new production measured in river-influenced shelf waters generally decreased with increasing depth, similar to what was observed in the upwelling region (Figure 6). Correlation between PP and NP was also high $(r=0.82$, Figure 4 ). The magnitude of primary production and new production also related significantly $(P<0 \cdot 01)$ to chlorophyll a concentration. Multiple regression analysis examining the effects of light availability and chlorophyll $a$ concentration revealed the following relationships:

$$
\begin{gathered}
\mathrm{PP}=0 \cdot 645+17 \cdot 80[\mathrm{Chl}]+0 \cdot 021 \mathrm{Light}\left(\mathrm{R}^{2}=0 \cdot 72\right) \\
\mathrm{NP}=-1 \cdot 092+8 \cdot 205[\mathrm{Chl}]+0 \cdot 008 \mathrm{Light}\left(\mathrm{R}^{2}=0 \cdot 48\right) ;
\end{gathered}
$$

Both riverine shelf water and upwelling water showed a similar pattern with maximum chlorophyll- specific production occurring in or near the surface layer, implying that their vertical distributions were light-dependent rather than nutrient-dependent. There were, however, observations at several stations that did not follow the trend that production decreased with depth. Light-dependence parameters obtained in this region are listed in Table 2. An example is shown for Station E2 where a significant relationship was not established (Figure 7).

Nitrate-based new production measured during cruise 449 ranged from 0.07 to $0.34 \mathrm{gC} \mathrm{m}^{-2}$ day ${ }^{-1}$ and primary production from 0.25 to $0.75 \mathrm{gC} \mathrm{m}^{-2}$ day $^{-1}$. In contrast to what was observed in the upwelling region, the variation of integrated new production was related to neither surface nitrate concentration, primary production, chlorophyll a concentration, nor incubation light intensity (Table 5). However, both f-ratio and the integrated chlorophyll-specific new production was significantly and positively related to the surface water temperature over the range $15-21{ }^{\circ} \mathrm{C}$ for all stations (Table 5). There was no significant relationship 
TABLE 3. Water column integrated primary production $\left(\mathrm{gC} \mathrm{m}^{-2}\right.$ day $\left.^{-1}\right)$, integrated new production $\left(\mathrm{gC} \mathrm{m}^{-2}\right.$ day $\left.^{-1}\right)$ and f-ratio obtained at seven sampling stations during three different cruises

\begin{tabular}{|c|c|c|c|c|c|c|c|}
\hline \multirow[b]{2}{*}{ Cruise } & \multicolumn{7}{|c|}{ Station } \\
\hline & 5 & 8 & $8 \mathrm{a}$ & 9 & 10 & $10 \mathrm{a}$ & 11 \\
\hline \multicolumn{8}{|c|}{ Primary production } \\
\hline 416 & $0 \cdot 43$ & & & $1 \cdot 00$ & & & $1 \cdot 03$ \\
\hline 124 & & $0 \cdot 71$ & $0 \cdot 88$ & $1 \cdot 32$ & $1 \cdot 22$ & $1 \cdot 96$ & \\
\hline 431 & & & & 0.66 & $0 \cdot 60$ & & $1 \cdot 43$ \\
\hline \multicolumn{8}{|c|}{ New production } \\
\hline 416 & $0 \cdot 08$ & & & $0 \cdot 77$ & & & $0 \cdot 66$ \\
\hline 124 & & $0 \cdot 30$ & $0 \cdot 32$ & $0 \cdot 36$ & $0 \cdot 80$ & $1 \cdot 61$ & \\
\hline 431 & & & & $0 \cdot 27$ & $0 \cdot 14$ & & $0 \cdot 72$ \\
\hline \multicolumn{8}{|l|}{ f-ratio } \\
\hline 416 & $0 \cdot 19$ & & & $0 \cdot 77$ & & & $0 \cdot 64$ \\
\hline 124 & & $0 \cdot 42$ & $0 \cdot 36$ & $0 \cdot 27$ & $0 \cdot 66$ & $0 \cdot 82$ & \\
\hline 431 & & & & $0 \cdot 41$ & $0 \cdot 23$ & & $0 \cdot 50$ \\
\hline
\end{tabular}

TABLE 4. Matrix of correlation coefficients ( $r$ ) for the variables f-ratio (INP/IPP), integrated new production (INP), integrated primary production (IPP), chlorophyll $a$ normalized integrated new production (INP/Ichl), chlorophyll $a$ normalized integrated primary production (IPP/Ichl), integrated chlorophyll $a$ concentration (Ichl), integrated nitrate concentration $\left(\mathrm{INO}_{3}\right)$, surface nitrate concentration $\left(\mathrm{NO}_{3}\right.$-surf), surface temperature (Temp-surf) and average surface light intensity (Light) obtained in the upwelling region northeast Taiwan

\begin{tabular}{|c|c|c|c|c|c|c|c|c|c|}
\hline Variables & f-ratio & INP & IPP & INP/Ichl & IPP/Ichl & Ichl & $\mathrm{INO}_{3}$ & $\mathrm{NO}_{3}$-surf & Temp-surf \\
\hline INP & $0 \cdot 88^{\star \star}$ & & & & & & & & \\
\hline IPP & $0 \cdot 67^{\star}$ & $0 \cdot 89^{\star \star}$ & & & & & & & \\
\hline INP/Ichl & $0 \cdot 87^{\star \star}$ & $0 \cdot 99^{\star \star}$ & $0 \cdot 87^{\star \star}$ & & & & & & \\
\hline IPP/Ichl & $0 \cdot 64^{\star}$ & $0 \cdot 87^{\star \star}$ & $0.96^{\star \star}$ & $0 \cdot 90^{\star \star}$ & & & & & \\
\hline Ichl & $0 \cdot 52$ & $0 \cdot 50$ & $0 \cdot 59$ & $0 \cdot 37$ & $0 \cdot 34$ & & & & \\
\hline $\mathrm{INO}_{3}$ & $-0 \cdot 16$ & -0.06 & $0 \cdot 16$ & -0.07 & $0 \cdot 12$ & $0 \cdot 20$ & & & \\
\hline $\mathrm{NO}_{3}$-surf & $0 \cdot 77^{\star \star}$ & $0 \cdot 86^{\star \star}$ & $0.73^{\star}$ & $0 \cdot 82^{\star \star}$ & $0 \cdot 68^{\star}$ & 0.50 & 0.02 & & \\
\hline Temp-surf & $-0 \cdot 34$ & -0.32 & $-0 \cdot 26$ & $-0 \cdot 24$ & $-0 \cdot 12$ & -0.45 & 0.49 & -0.53 & \\
\hline Light & $0 \cdot 68^{\star}$ & $0 \cdot 46$ & $0 \cdot 46$ & $0 \cdot 45$ & $0 \cdot 42$ & $0 \cdot 50$ & $0 \cdot 19$ & $0 \cdot 48$ & $-0 \cdot 22$ \\
\hline
\end{tabular}

${ }^{\star} P<0 \cdot 05,{ }^{\star} \times P<0 \cdot 01$.

between the new production and the surface nitrate concentration (Table 5).

Light intensity seemed not to be crucial in affecting the spatial variation of integrated new production on the continental shelf off the Changjiang. There was no significant relationship between integrated new production and the average on-deck light intensity during incubation. There was a subsurface maxima of new production at Station E2 (Figure 7) where the surface nitrate concentration was high and the integrated new production was low. Maximum new production was located at $10-15 \mathrm{~m}$ (four times greater than that at $2 \mathrm{~m}$ ) in the euphotic zone where nitrate was abundant and uniformly distributed. Similarly high, subsurface new production was also observed at Stations E1, E7 and E6.
Water column f-ratio ranged between $0 \cdot 17$ (Station E2) and 0.51 (Station E6) (Table 6). Its variation was positively related to surface water temperature (Table 5), but not to light intensity, surface nitrate concentration, and integrated nitrate concentration (Table 5).

\section{Discussion}

\section{Data review, $N P$ and $P P$}

The present study reports the first values of nitratebased new production on the continental shelf of the East China Sea. Rates ranged from 80 to $1610 \mathrm{mgC} \mathrm{m}^{-2}$ day $^{1}$ in the upwelling region and from 70 to $340 \mathrm{mgC} \mathrm{m}^{-2}$ day $^{-1}$ in the broad shelf 

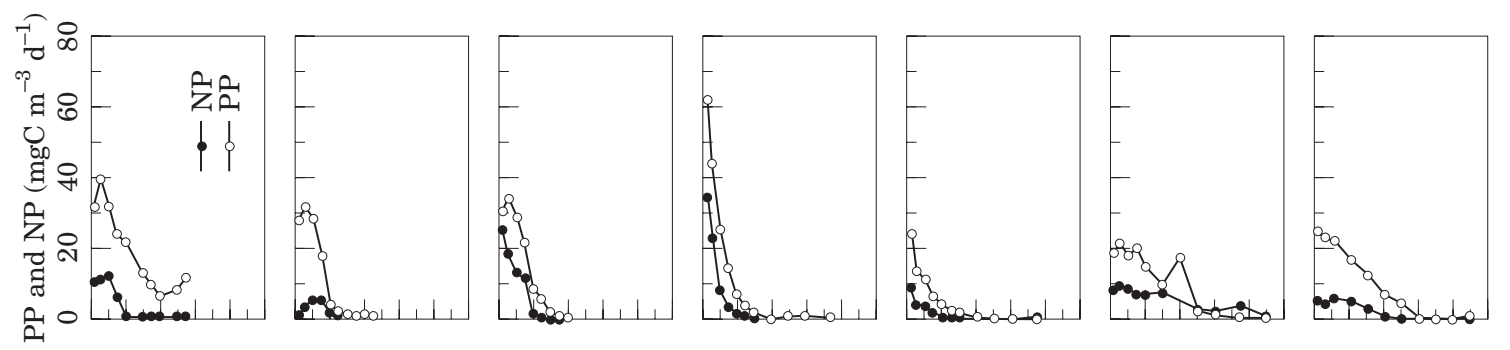

政
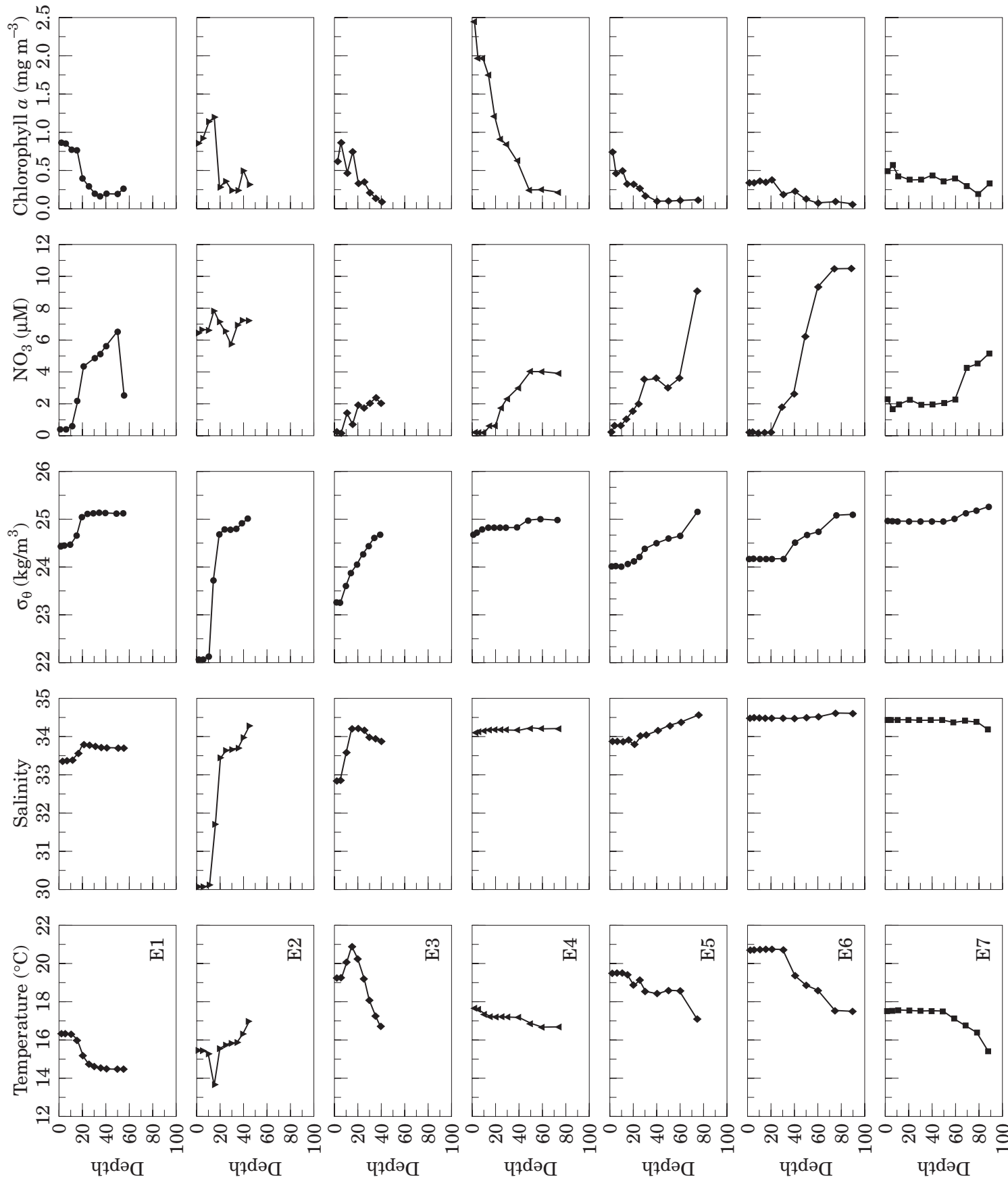

чұवәव

чұवәव

чұवәС

чұdәС

чұवәС

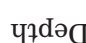

प7dәव

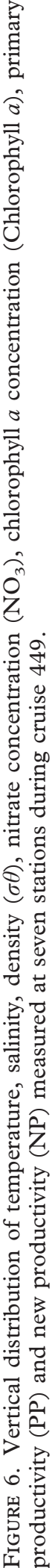




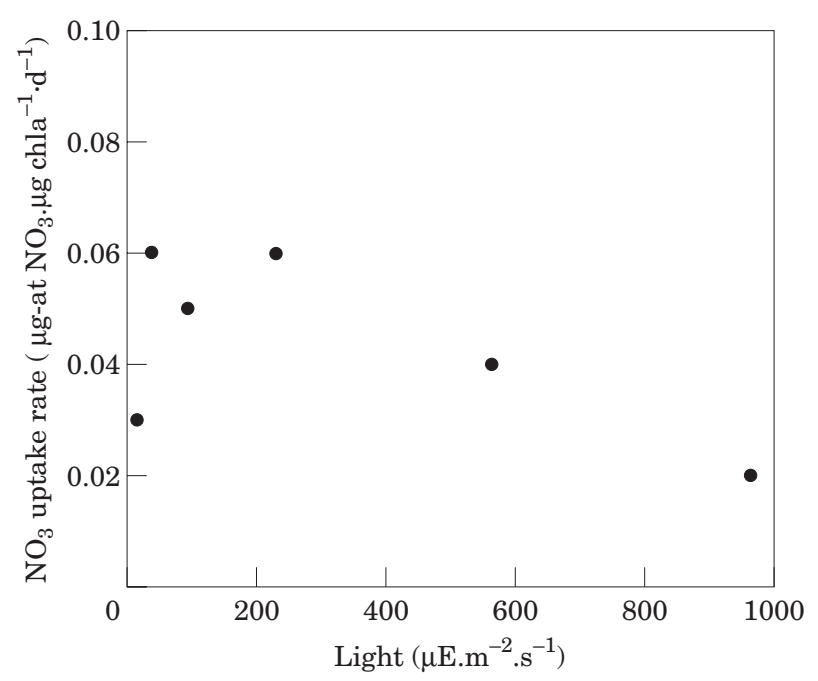

FIGURE 7 . Relationship between light intensity $\left(\mu \mathrm{E} \mathrm{m}^{-2}\right.$ $\left.\mathrm{S}^{-1}\right)$ and nitrate uptake rate $\left(\mu \mathrm{g}\right.$ at $\left.-\mathrm{N} \mu \mathrm{g} \mathrm{Chl}^{-1} \mathrm{day}^{-1}\right)$ at Station E2.

area including the Changjiang-influenced waters. These values are much higher than previously calculated estimates of $80 \mathrm{mgC} \mathrm{m}^{-2}$ day $^{-1}$ by $\mathrm{Li}$ (1995) and $73 \pm 22 \mathrm{mgC} \mathrm{m}^{-2}$ day $^{-1}$ by Chen (1996). Similarly, much higher f-ratios were obtained from our direct measurements $(0 \cdot 17-0 \cdot 82)$ than those estimated by Chen $(0 \cdot 15)$ and by $\mathrm{Li}(<0 \cdot 16)$. Average f-ratio was 0.48 for the upwelling region and 0.34 for the Changjiang continental shelf region. These average values were computed by placing equal weight on each of the stations, regardless of their uneven distribution and sampling frequency. For comparison, f-ratios as low as 0.05 were reported for oligotrophic central oceans and as high as 0.5 in a productive coastal-upwelling regions (Harrison et al., 1987).

Primary production observed in this study ranged from 430 to $1960 \mathrm{mgC} \mathrm{m}^{-2}$ day $^{-1}$ in the upwelling region (Table 3 ). The data are consistent with previous observations in a similar area (Chen, 1995b). The values ranged from 250 to $750 \mathrm{mgC} \mathrm{m}^{-2}$ day $^{-1}$ in the shelf region off Changjiang (Table 6), and also comparable with, but slightly lower than, the value obtained by Hama et al. (1997), who reported the average primary productivity of $750 \mathrm{mgC} \mathrm{m}^{-2}$ day $^{-1}$ for the shelf area close to this study. High productivity in the ECS, especially at the upwelling plume was confirmed in this study.

\section{Effect of upwelling on NP}

Both new production and primary production in the upwelling region are under strong control of nutrient supply via upwelling. $\mathrm{N}$ is generally considered to be a limiting element in the dynamics of new production. This is clearly shown in the upwelling region of the present study (Figure 8). The upwelling INP and IPP were related to $\mathrm{NO}_{3}$-surf, but not to $\mathrm{INO}_{3}$. This implies that INP and IPP are responding to a factor to which $\mathrm{NO}_{3}$-surf is related, not necessarily to $\mathrm{NO}_{3}{ }^{-}$ concentration itself. $\mathrm{NO}_{3}$-surf likely represents 'strength' of the upwelling or the rate of supply of deep water and $\mathrm{N}$ to the photic zone. The present upwelling had a maximum surface nitrate concentration of $2 \mu \mathrm{M}$ and f-ratios of $0 \cdot 23-0 \cdot 82$. In contrast, the Peruvian upwelling has f-ratios of $0 \cdot 10-0 \cdot 84$ and a maximum surface nitrate concentration of $>20 \mu \mathrm{M}$ (Wilkerson \& Dugdale, 1987). Nitrate supply from the subsurface Kuroshio waters to these subtropical waters appears to contribute in a similar manner to primary production as in the Peruvian upwelling. The high f-ratio and correlation of INP and $\mathrm{NO}_{3}$-surf in this study indicate that phytoplankton response to the upwelling is faster than in the Peruvian upwelling system, where time-lags of phytoplankton growth are often observed.

The distribution of high new production and f-ratio matched the distribution of low temperature and high nitrate concentration at the centre of the upwelling water. The chain reaction from physical effect (upwelling) to chemical change (high nitrate) to the biological response (high INP) was clearly demonstrated. The behaviour of the Kuroshio Current therefore is an important force in determining the dynamics of new production in these shelf waters.

\section{Control of the Changjiang NP:(1) Temperature}

Unlike the Kuroshio Current, the nitrate-rich Changjiang runoff did not bring similarly high, nitrate-based new production to its immediate shelf water. Station E2 with a surface nitrate concentration as high as $6 \cdot 4 \mu \mathrm{M}$, higher than the maximum surface concentration of $2 \mu \mathrm{M}$ observed in the upwelling, had the lowest new production $\left(70 \mathrm{mgC} \mathrm{m}^{-2}\right.$ day $\left.^{-1}\right)$ and f-ratio $(0 \cdot 17)$ of all stations (Figure 8$)$. The subsurface Kuroshio water is warm and salty in contrast to the cold and less saline turbid Changiiang plume. Water temperature was positively related to new production off the Changjiang continental shelf region. The Changjiang-influenced water was both low in surface temperature and new production. Positive correlation between water temperature and nitrate uptake rate has been previously reported (Slawyk, 1979; Le Bouteillier, 1986) where factors such as light intensity and nutrient concentration were relatively uniform. There are conflicting reports depicting the linkage 
TABLE 5. Matrix of correlation coefficients ( $r$ ) for the variables f-ratio (INP/IPP), integrated new production (INP), integrated primary production (IPP), chlorophyll $a$ normalized integrated new production (INP/Ichl), chlorophyll $a$ normalized integrated primary production (IPP/Ichl), integrated chlorophyll $a$ concentration (Ichl), integrated nitrate concentration $\left(\mathrm{INO}_{3}\right)$, surface nitrate concentration $\left(\mathrm{NO}_{3}\right.$-surf), surface temperature (Temp-surf) and average surface light intensity (Light) obtained in the continental shelf region off the Changjiang

\begin{tabular}{|c|c|c|c|c|c|c|c|c|c|}
\hline Variables & f-ratio & INP & IPP & INP/Ichl & IPP/Ichl & Ichl & $\mathrm{INO}_{3}$ & $\mathrm{NO}_{3}$-surf & Temp-surf \\
\hline INP & $0 \cdot 79^{\star}$ & & & & & & & & \\
\hline IPP & $-0 \cdot 14$ & 0.47 & & & & & & & \\
\hline INP/Ichl & 0.73 & $0 \cdot 88^{\star \star}$ & $0 \cdot 34$ & & & & & & \\
\hline IPP/Ichl & $0 \cdot 10$ & 0.54 & $0 \cdot 72$ & 0.73 & & & & & \\
\hline Ichl & -0.02 & $0 \cdot 01$ & $0 \cdot 09$ & $-0 \cdot 47$ & -0.57 & & & & \\
\hline $\mathrm{INO}_{3}$ & $-0 \cdot 21$ & $0 \cdot 01$ & $0 \cdot 12$ & $0 \cdot 28$ & $0 \cdot 41$ & -0.53 & & & \\
\hline $\mathrm{NO}_{3}$-surf & $-0 \cdot 67$ & -0.57 & $-0 \cdot 14$ & -0.49 & $-0 \cdot 26$ & 0.03 & $0 \cdot 46$ & & \\
\hline Temp-surf & $0 \cdot 87^{\star}$ & $0 \cdot 67$ & $-0 \cdot 13$ & $0 \cdot 76^{\star}$ & $0 \cdot 25$ & -0.34 & $0 \cdot 08$ & -0.68 & \\
\hline Light & $-0 \cdot 34$ & $-0 \cdot 14$ & $0 \cdot 17$ & $0 \cdot 10$ & $0 \cdot 32$ & -0.48 & $0 \cdot 41$ & $0 \cdot 60$ & $-0 \cdot 22$ \\
\hline
\end{tabular}

${ }^{\star} P<0 \cdot 05,{ }^{\star}{ }^{\star} P<0 \cdot 01$

TABLE 6. Spatial variation of water column integrated primary production $\left(\mathrm{gC} \mathrm{m}^{-2} \mathrm{day}^{-1}\right)$, integrated new production $\left(\mathrm{gC} \mathrm{m}^{-2}\right.$ day $^{-1}$ ) and f-ratio obtained in the continental shelf off the Changjiang during cruise 449

\begin{tabular}{lccccccc}
\hline & \multicolumn{7}{c}{ Station } \\
\cline { 2 - 7 } & E1 & E2 & E3 & E4 & E5 & E6 & E7 \\
\hline Primary production & $0 \cdot 75$ & $0 \cdot 43$ & $0 \cdot 52$ & $0 \cdot 50$ & $0 \cdot 25$ & $0 \cdot 66$ & $0 \cdot 71$ \\
New Production & $0 \cdot 16$ & $0 \cdot 07$ & $0 \cdot 25$ & $0 \cdot 21$ & $0 \cdot 09$ & $0 \cdot 34$ & $0 \cdot 16$ \\
f-ratio & $0 \cdot 21$ & $0 \cdot 17$ & $0 \cdot 48$ & $0 \cdot 43$ & $0 \cdot 36$ & $0 \cdot 51$ & $0 \cdot 23$ \\
\hline
\end{tabular}

between surface temperature and new production. Kamykowski and Zentara (1986) found that surface temperature of water in an upwelling system was low whilst concentration of nitrate was high; new production was high in upwelled water despite the low surface temperature. However temperature effect in this study could also be a surrogate of the effects linking to the water mass rather than its direct physiological influence on phytoplankton cells.

\section{Control of the Changiiang NP:(2) $\mathrm{PO}_{4}$}

Although the upwelling and the Changiianginfluenced waters were both rich in nitrate, there were differences in other nutrient concentrations. Our study showed that in situ measurements of $\mathrm{N}: \mathrm{P}$ ratios $\left(\left[\mathrm{NO}_{3}{ }^{-}\right] /\left[\mathrm{PO}_{4}{ }^{3-}\right]\right)$ in the water column of the euphotic zone were mostly below the Redfield ratio of 16:1 (Table 7), with the exception of Station E2. This indicates that most of the water on the shelf was potentially more insufficient in nitrate than in phosphate. On the contrary, N:P ratios as high as 213.3 were observed in the surface water of Station E2, and its phosphate concentration was at the limit of detection $(0.03 \mu \mathrm{M})$. Phosphate concentration was undetectable in the upper $20 \mathrm{~m}$ of Station E4. This implies that within the river-influenced water, such as Station E2, the limitation on production was probably from phosphate instead of $\mathrm{N}$. There were other reasons for supporting the differences in $\mathrm{N}: \mathrm{P}$ ratio between these two nitrate-rich waters. Chen (1996) reported that the nutrient flux from the Kuroshio water to the shelf was $14 \cdot 3: 1$ which is close to the $16: 1$ Redfield ratio, whereas $\mathrm{N}$ (nitrate + ammonium): $\mathrm{P}$ ratio from the Changjiang river fluxes was 126:1. A steep gradient of nitrate $(65-15 \mu \mathrm{M})$, phosphate $(0 \cdot 7-0 \mu \mathrm{M})$ and $\mathrm{N}: \mathrm{P}$ ratio $(90-150)$ was found over the salinity gradient from the river mouth to the open sea (Harrison et al., 1990). Mesocosm experiments off the coast of mainland China indicated that phytoplankton growth was limited by phosphorus rather than by $\mathrm{N}$ (Harrison et al., 1990). Station E2 had a surface salinity of 30.04 and was within the range of 0 to 32 in the phosphate-limiting region described by Harrison et al. (1990). It is, thus, very likely that the water at this station was phosphate-limited rather 

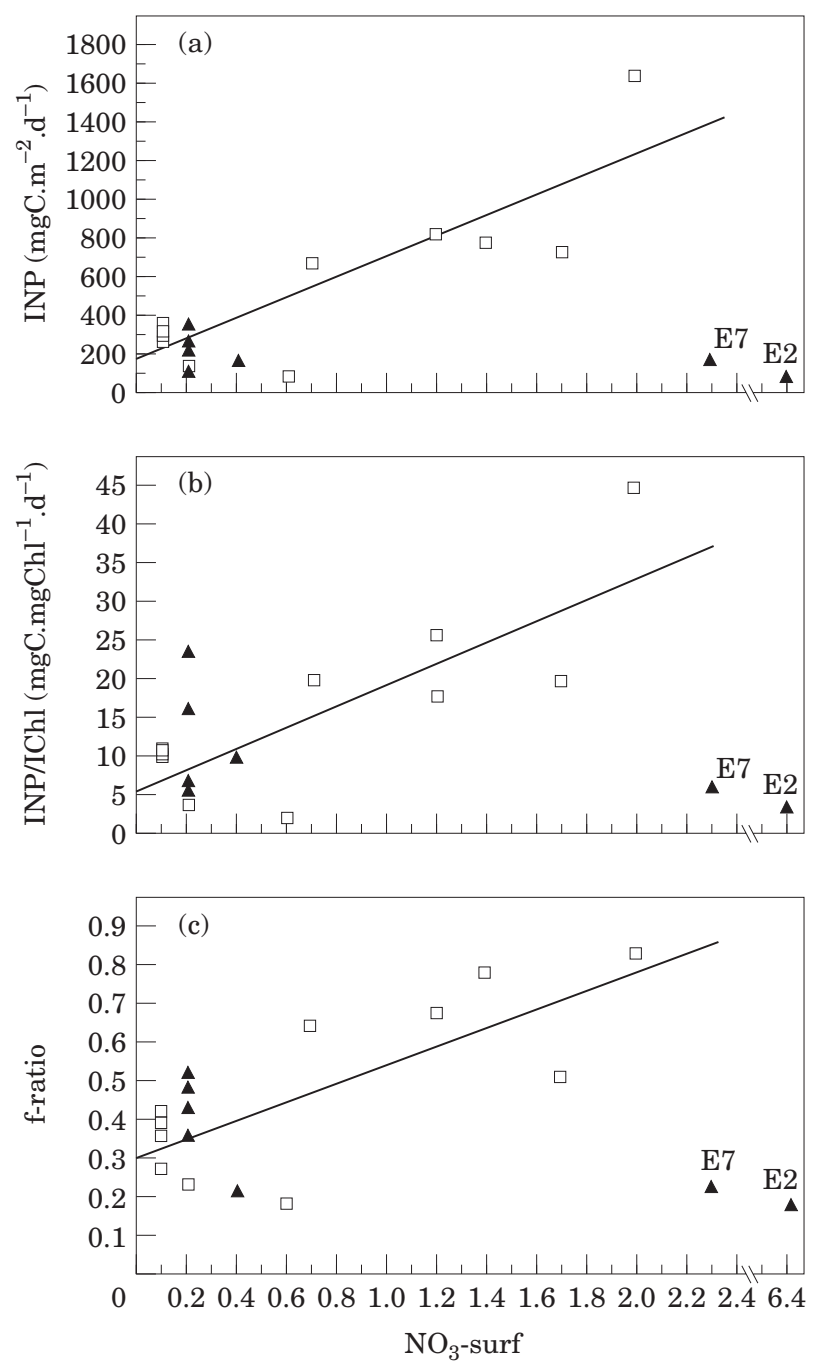

FIGURE 8. Relationships between surface nitrate concentration and integrated new production (a), chlorophyll $a$ normalized integrated new production (b), and f-ratio (c), measured in the upwelling region ( $\square$ ) and in the continental shelf off the Changjiang ( $\mathbf{A})$. Regression line was calculated based on the data in the upwelling region during three cruises.

than $\mathrm{N}$-limited, as has been reported seasonally for other river-influenced regions such as Chesapeake Bay (e.g. Fisher et al., 1992).

\section{Control of the Changjiang NP:(3) Light}

As well as ambient nitrate concentration light intensity is another important factor (Kanda et al., 1989) in affecting nitrate uptake. The waters of the Changiiang carry a high concentration of suspended matter (Tian et al., 1993). These river-borne particulates are maintained in suspension in the surface layer to salinities $>20$, and their concentrations vary between 20 and
$1000 \mathrm{mg} \mathrm{l}^{-1}$ and decrease to $10 \mathrm{mg} \mathrm{l}^{-1}$ with higher salinity (Edmond et al., 1985). Light availability increases as the suspended particulate matter settles (Ning et al., 1988). The nitrate uptake rate, integrated over the water column, measured in the Changjiang continental shelf water, however, did not show any significant relationship with the light intensity in the present study. The water which was most likely to be affected by the riverine input (Station E2) showed a rather deep euphotic depth $(29 \mathrm{~m}$, Table 1$)$ and high incubation light intensity $\left(1383 \mu \mathrm{E} \mathrm{m}^{-2} \mathrm{~S}^{-1}\right)$ when compared with the same parameters at station $\mathrm{E} 4$ $\left(27 \mathrm{~m}\right.$ and $332 \mu \mathrm{E} \mathrm{m}^{-2} \mathrm{~S}^{-1}$ ), with double the amount of new productivity. Density $(\sigma \theta)$ profiles showed that Station E2 was highly stratified and its mixing depth was shallow (Figure 6) compared to the euphotic zone depth. This suggested that the slow uptake of nitrate in the upper water column of the station was not due to limitation by light intensity. The observation that incubation light intensity was not significantly correlated with specific nitrate uptake rate at that station (Figure 7 ) provides further direct evidence. Low INP $(161 \cdot 55)$, low f-ratio $(0 \cdot 23)$ as well as high surface nitrate concentration $(2 \cdot 3 \mu \mathrm{M}$, Figure 8) was also observed at Station E7. Limitation due to light intensity seems to be unlikely due to the relatively high light intensity $\left(1243 \mu \mathrm{E} \mathrm{m}^{-2} \mathrm{~S}^{-1}\right)$ and low light extinction coefficient $(0.077)$ during the incubation. However, the low uptake rates of nitrate at Station E7 could be attributed to lack of vertical stratification in the water column. The mixed layer of Station E7 was $60 \mathrm{~m}$ (Figure 6), and deep mixing reduces average light intensity available for phytoplankton, which then become light-limited instead of nutrient-limited. Stratification is considered important to stimulate the onset of spring phytoplankton growth in many coastal waters such as Chesapeake Bay and Delaware Bay (Pennock \& Sharp, 1990; Glibert et al., 1995). Phosphate limitation was also unlikely because the surface phosphate concentration of $0 \cdot 21 \mu \mathrm{M}$ was relatively moderate. The influence of river discharge on Station E7 was minimal because its surface salinity was $34 \cdot 45$.

\section{Contribution of other new $N$ to the ECS new production}

The new production and f-ratio in our study would be even higher if $\mathrm{N}$ fixation from Trichodesmium sp. and Richelia intracellularis, a symbiont within diatoms Rhizosolenia spp. and Hemiaulus spp., were also included in the measurement of new production. Trichodesmium sp. is abundant in the Kuroshio Current and the water where the Kuroshio Current encounters the coastal water (Marumo \& Asaoka, 
TABLE 7. Nitrate and phosphate concentrations as well as nitrate/phosphate (N/P) ratios measured at various sampling stations in the upwelling region (Cruises 416, 124 and 431) and the continental shelf region off the Changjiang estuary (Cruise 449)

\begin{tabular}{|c|c|c|c|c|c|c|c|c|c|}
\hline Station & $\begin{array}{l}\text { Depth } \\
\text { (m) }\end{array}$ & $\begin{array}{l}\mathrm{NO}_{3} \\
(\mu \mathrm{M})\end{array}$ & $\begin{array}{l}\mathrm{PO}_{4} \\
(\mu \mathrm{M})\end{array}$ & $\mathrm{N} / \mathrm{P}$ & Station & $\begin{array}{l}\text { Depth } \\
\text { (m) }\end{array}$ & $\begin{array}{l}\mathrm{NO}_{3} \\
(\mu \mathrm{M})\end{array}$ & $\begin{array}{l}\mathrm{PO}_{4} \\
(\mu \mathrm{M})\end{array}$ & $\mathrm{N} / \mathrm{P}$ \\
\hline Cruise 416 & & & & & Cruise 449 & & & & \\
\hline \multirow[t]{3}{*}{5} & 0 & $1 \cdot 09$ & 0.58 & $1 \cdot 9$ & E1 & 2 & $0 \cdot 40$ & 0.05 & $8 \cdot 0$ \\
\hline & 50 & 0.51 & $0 \cdot 54$ & $0 \cdot 9$ & & 20 & $4 \cdot 10$ & $0 \cdot 21$ & $19 \cdot 5$ \\
\hline & 75 & $1 \cdot 00$ & 0.52 & 1.9 & & 40 & $5 \cdot 34$ & $0 \cdot 24$ & $22 \cdot 3$ \\
\hline \multirow{3}{*}{11} & 0 & $0 \cdot 49$ & 0.43 & $1 \cdot 1$ & & 50 & $6 \cdot 29$ & $0 \cdot 31$ & $20 \cdot 3$ \\
\hline & 50 & $2 \cdot 90$ & $0 \cdot 72$ & $4 \cdot 0$ & $\mathrm{E} 2$ & 2 & $6 \cdot 40$ & 0.03 & $213 \cdot 3$ \\
\hline & 100 & $6 \cdot 20$ & 0.57 & $10 \cdot 9$ & & 10 & $6 \cdot 41$ & $0 \cdot 06$ & $106 \cdot 8$ \\
\hline Cruise 124 & & & & & & 15 & $7 \cdot 50$ & $0 \cdot 20$ & $37 \cdot 5$ \\
\hline \multirow[t]{3}{*}{8} & 0 & $0 \cdot 00$ & $0 \cdot 48$ & $0 \cdot 0$ & & 25 & $6 \cdot 34$ & $0 \cdot 25$ & $25 \cdot 4$ \\
\hline & 50 & $1 \cdot 68$ & 0.67 & $2 \cdot 5$ & & 40 & $6 \cdot 94$ & $0 \cdot 27$ & $25 \cdot 7$ \\
\hline & 100 & $10 \cdot 23$ & $1 \cdot 16$ & $8 \cdot 8$ & E3 & 2 & $0 \cdot 20$ & $0 \cdot 24$ & $0 \cdot 8$ \\
\hline \multirow[t]{3}{*}{$8 \mathrm{a}$} & 0 & $0 \cdot 11$ & 0.50 & $0 \cdot 2$ & & 10 & $1 \cdot 17$ & $0 \cdot 10$ & $11 \cdot 7$ \\
\hline & 50 & $2 \cdot 73$ & $0 \cdot 70$ & $3 \cdot 9$ & & 19 & $1 \cdot 61$ & $0 \cdot 10$ & $16 \cdot 1$ \\
\hline & 100 & $9 \cdot 81$ & $1 \cdot 11$ & $8 \cdot 8$ & & 40 & $1 \cdot 77$ & $0 \cdot 17$ & $10 \cdot 4$ \\
\hline \multirow[t]{3}{*}{9} & 0 & $0 \cdot 15$ & $0 \cdot 54$ & $0 \cdot 3$ & $\mathrm{E} 4$ & 2 & $0 \cdot 20$ & $<0.03$ & $>6 \cdot 7$ \\
\hline & 50 & $4 \cdot 66$ & $0 \cdot 74$ & $6 \cdot 3$ & & 10 & $0 \cdot 16$ & $<0.03$ & $>5 \cdot 3$ \\
\hline & 100 & $6 \cdot 92$ & 0.95 & $7 \cdot 3$ & & 20 & $0 \cdot 50$ & $<0.03$ & $>16 \cdot 7$ \\
\hline \multirow[t]{3}{*}{10} & 0 & $0 \cdot 20$ & 0.59 & $0 \cdot 3$ & & 24 & 1.63 & 0.05 & $32 \cdot 6$ \\
\hline & 50 & $6 \cdot 60$ & $0 \cdot 80$ & $8 \cdot 3$ & & 60 & $3 \cdot 82$ & $0 \cdot 24$ & $15 \cdot 9$ \\
\hline & 100 & $9 \cdot 63$ & $1 \cdot 03$ & $9 \cdot 4$ & E5 & 2 & $0 \cdot 20$ & $0 \cdot 11$ & $1 \cdot 8$ \\
\hline \multirow[t]{3}{*}{$10 \mathrm{a}$} & 0 & 0.05 & 0.56 & $0 \cdot 1$ & & 9 & 0.55 & $0 \cdot 14$ & $3 \cdot 9$ \\
\hline & 50 & $5 \cdot 48$ & $0 \cdot 89$ & $6 \cdot 2$ & & 20 & $1 \cdot 39$ & $0 \cdot 19$ & $7 \cdot 3$ \\
\hline & 100 & $10 \cdot 56$ & $1 \cdot 20$ & $8 \cdot 8$ & & 40 & $3 \cdot 19$ & $0 \cdot 21$ & $15 \cdot 2$ \\
\hline Cruise 431 & & & & & & 75 & $8 \cdot 97$ & 0.67 & $13 \cdot 4$ \\
\hline \multirow[t]{3}{*}{9} & 0 & $0 \cdot 00$ & $0 \cdot 08$ & $0 \cdot 0$ & E6 & 2 & $0 \cdot 20$ & $0 \cdot 07$ & $2 \cdot 9$ \\
\hline & 40 & $2 \cdot 89$ & $0 \cdot 34$ & $8 \cdot 5$ & & 20 & $0 \cdot 12$ & $0 \cdot 10$ & $1 \cdot 2$ \\
\hline & 68 & $8 \cdot 52$ & $0 \cdot 45$ & $18 \cdot 9$ & & 40 & $2 \cdot 04$ & $0 \cdot 22$ & $9 \cdot 3$ \\
\hline \multirow[t]{3}{*}{10} & 0 & $0 \cdot 16$ & 0.05 & $3 \cdot 2$ & & 60 & $9 \cdot 23$ & $0 \cdot 62$ & $14 \cdot 9$ \\
\hline & 45 & $4 \cdot 78$ & $0 \cdot 43$ & $11 \cdot 1$ & E7 & 2 & $2 \cdot 30$ & $0 \cdot 21$ & $11 \cdot 0$ \\
\hline & 100 & $8 \cdot 71$ & $0 \cdot 72$ & $12 \cdot 1$ & & 10 & $1 \cdot 83$ & $0 \cdot 23$ & $8 \cdot 0$ \\
\hline \multirow[t]{3}{*}{11} & 0 & $1 \cdot 74$ & $0 \cdot 14$ & $12 \cdot 4$ & & 30 & 1.97 & $0 \cdot 23$ & $8 \cdot 6$ \\
\hline & 50 & $4 \cdot 48$ & 0.46 & $9 \cdot 7$ & & 50 & $2 \cdot 03$ & $0 \cdot 22$ & $9 \cdot 2$ \\
\hline & 84 & $10 \cdot 40$ & $0 \cdot 89$ & $11 \cdot 7$ & & 69 & $4 \cdot 32$ & $0 \cdot 28$ & $15 \cdot 4$ \\
\hline
\end{tabular}

1974). Trichodesmium is capable of very high rates of $\mathrm{N}$ fixation (14.0 $\mathrm{ngN} \mu \mathrm{g}$ algal $\mathrm{N}^{-1} \mathrm{~h}^{-1}$; Saino \& Hattori, 1978). Moreover its density could reach $10^{2}-10^{3}$ filaments per liter in summer (Marumo \& Nagasawa, 1976). However, the effects of Trichodesmium spp. and Richelia containing diatoms were not studied intensively enough in our research to enable the estimation of this portion of new production. The summertime $\mathrm{N}$ fixation by $T$. thiebautii was estimated to be $8 \times 10^{10} \mathrm{gN}$ in the south-eastern East China Sea and accounted for approximately $6 \%$ of the $\mathrm{N}$ requirements for primary productivity (Saino \& Hattori, 1980). In addition, a relatively high concentration of ammonium $(14.6 \mu \mathrm{M})$ was also reported in the Changjiang water (Zhang, 1996). This corresponds to about half of the average concentration of nitrate in the run-off (Zhang, 1996). Urea and other DON should also be accounted for, but the available data are scarce. The contribution to primary production from these $\mathrm{N}$ sources was a part of the new production, at least in those areas influenced by the river runoff, such as Stations E1 and E2. Therefore the real f-ratio would be higher than that obtained in our measurements, which were based solely on nitrate uptake. By simple calculation from the quantity of nitrate flux, Chen (1996) estimated the contribution from the Kuroshio upwelling to be many times greater than the inputs from the Changjiang and the Yellow River combined. With our findings that nitrate contributed more to new production in the upwelling waters than in the riverine waters, the importance of the input from the Kuroshio compared with the Changiiang river is further emphasized. However, the contribution of ammonium and DON in river water 
may be significant and hence the river contribution could be larger. Additional studies on a larger scale dealing with seasonal variations and the spatial extent of both the river plume and upwelling are warranted to understand the relative importance of the two $\mathrm{N}$ sources in the dynamics of new production in the East China Sea.

\section{Acknowledgements}

The authors thank Miss W. H. Lee for assistance in chlorophyll $a$ and new production measurements. The cooperation of the captains and crew of the R/V Ocean Researcher $I$ and $I I$ during the sampling is appreciated. The authors are grateful to Dr Timothy Parsons for reading a draft version of this manuscript. The authors would also like to thank two anonymous reviewers for helpful suggestions. This research was supported in part by grants (NSC 85-2611M110-009K2 and 86-2611-M110-008K2) from the National Science Council of the Republic of China.

\section{References}

Chen, C.-T. A. 1996 The Kuroshio intermediate water is the major source of nutrients on the East China Sea continental shelf. Oceanologica Acta 19, 5, 523-527.

Chen, Y. L. L. 1992 Summer phytoplankton community structure in the Kuroshio current-related upwelling northeast of Taiwan. Terrestrial, Atmospheric and Oceanic Sciences 3, 305-320.

Chen, Y. L. L. 1994 The importance of temperature and nitrate to the distribution of phytoplankton in the Kuroshio-induced upwelling, northeast of Taiwan. Proceedings of the National Science Council-Part B: Life Sciences 18, 44-51.

Chen, Y. L. L. 1995a Temporal and spatial changes of chlorophyll $a$ in the KEEP study waters off northern Taiwan. Terrestrial, Atmospheric and Oceanic Sciences 6, 607-620.

Chen, Y. L. L. $1995 b$ Phytoplankton composition and productivity in response to the upwelling off northeastern Taiwan. Proceedings of the National Science Council-Part B: Life Sciences 19, 66-72.

Chern, C. S., Wang, J. \& Wang, D. P. 1990 The exchange of Kuroshio and East China Sea shelf water. Fournal of Geophysical Research 95, 16 017-16 023.

Draper, N. R. \& Smith, H. 1981 Applied Regression Analysis. John Wiley \& Sons, New York, 709 pp.

Dugdale, R. C. \& Goering, J. J. 1967 Uptake of new and regenerated forms of nitrogen in primary productivity. Limnology and Oceanography 12, 196-206.

Dugdale, R. C. \& Wilkerson, F. P. 1986 The use of 15 N to measure nitrogen uptake in eutrophic oceans: experimental considerations. Limnology and Oceanography 31, 673-689.

Dugdale, R. C., Morel, A., Bricaud, A. \& Wilkerson, F. P. 1989 Modeling new production in upwelling centers: a case study of modeling new production from remotely sensed temperature and color. Fournal of Geophysical Research 94, 18119-18132.

Edmond, J. M., Spivack, A., Grant, B. C., Hu, M., Chen, Z., Chen, S. \& Zeng, X. 1985 Chemical dynamics of the Changiiang estuary. Continental Shelf Research 4, 17-36.

Fisher, T. R., Peele, E. R., Ammerman, J. W. \& Harding, L. W. 1992 Nutrient limitation of phytoplankton in Chesapeake Bay. Marine Ecology Progress Series 82, 51-63.
Glibert, P. M., Conley, D. J., Fisher, T. R., Harding Jr. L. W. \& Malone, T. C. 1995 Dynamics of the 1990 winter/spring bloom in Chesapeake Bay. Marine Ecology Progress Series 122, 27-43.

Hama, T., Miyazaki, T., Ogawa, Y., Iwakumi, T., Takahashi, M., Otsuki, A. \& Ichimura, S. 1983 Measurement of photosynthetic production of a marine phytoplankton population using a stable ${ }^{13} \mathrm{C}$ isotope. Marine Biology 73, 31-36.

Hama, T., Shin, K. H. \& Handa, N. 1997 Spatial variability in the primary productivity in the East China Sea and its adjacent waters. Fournal of Oceanography 53, 41-51.

Harrison, W. G., Platt, T. \& Lewis, M. R. 1987 f-Ratio and its relationship to ambient nitrate concentration in coastal waters. Fournal of Plankton Research 9, 235-248.

Harrison, P. J., Hu, M. H., Yang, Y. P. \& Lu, X. 1990 Phosphate limitation in estuarine and coastal waters of China. Fournal of Experimental Marine Biology and Ecology 140, 79-87.

Kamykowski, D. \& Zentara, S. J. 1986 Predicting plant nutrient concentration from temperature and sigma-t in the upper kilometer of the world ocean. Deep-Sea Research 33, 89-105.

Kanda, J., Ziemann, D. A., Conquest, L. D. \& Bienfang, P. K. 1989 Light-dependency of nitrate uptake by phytoplankton over the spring bloom in Auke Bay, Alaska. Marine Biology 103, 563-569.

Le Bouteiller, A. 1986 Environmental control of nitrate and ammonium by phytoplankton in the Equatorial Atlantic Ocean. Marine Ecology Progress Series 30, 167-179.

Li, Y. H. 1995 Material exchange between the East China Sea and the Kuroshio Current. Terrestrial, Atmospheric and Oceanic Sciences 5, 625-631.

Marumo, R. \& Asaoka, O. 1974 Distribution of pelagic blue-green algae in the North Pacific Ocean. Fournal of the Oceanographical Society of Japan 30, 77-85.

Marumo, R. \& Nagasawa, S. 1976 Seasonal variation of the standing crop of a pelagic blue-green alga, Trichodesmium in the Kuroshio water. Bulletin of Plankton Society of Fapan 23, 19-25.

Ning, X., Vaulot, D., Liu, Z. \& Liu, Z. 1988 Standing stock and production of phytoplankton in the estuary of the Changiiang (Yangtse River) and the adjacent East China Sea. Marine Ecology Progress Series 49, 141-150.

Parsons, T. R., Maita, Y. \& Lalli, C. M. 1984 A Manual of Chemical and Biological Methods for Seawater Analysis. Pergamon Press, pp. 173.

Pennock, J. R. \& Sharp, J. H. 1990 Biogeochemical regulation of nitrogen cycling in the Delaware Estuary-The constraints of light-limited phytoplankton growth. Abstracts of Papers of the American Chemical Society 199, 37.

Saino, T. \& Hattori, A. 1978 Diel variation in nitrogen fixation by a marine blue-green alga Trichodesmium thiebautii. Deep-Sea Research 25, 1259-1263.

Saino, T. \& Hattori, A. 1980 Nitrogen fixation by Trichodesmium and its significance in nitrogen cycling in the Kuroshio area and adjacent waters. In The Kuroshio IV. Proceedings of the Fourth Symposium for the Cooperative Study of the Kuroshio and Adjacent Regions, The Japan Academy, Tokyo, 14-17 February, 1979, pp. 697-709.

Slawyk, G. $1979{ }^{13} \mathrm{C}$ and ${ }^{15} \mathrm{~N}$ uptake by phytoplankton in the Antarctic upwelling area: Results from the Antipod I Cruise in the Indian Ocean sector. Australian fournal of Marine and Freshwater Research 30, 431-448.

Strickland, J. D. H. \& Parsons, T. R. 1972 A Practical Handbook of Seawater Analysis. Bulletin of Fisheries Research Board of Canada $167,1-310$.

Tian, R. C., Hu, F. X. \& Martin, J. M. 1993 Summer nutrient fronts in the Changjiang (Yangtze River) estuary. Estuarine, Coastal and Shelf Science 37, 27-41.

Vezina, A. F. \& Platt, T. 1987 Small-scale variability of new production and particulate fluxes in the ocean. Canadian fournal of Fisheries and Aquatic Science 44, 198-205.

Vitousek, P. M. \& Howarth, R. W. 1991 Nitrogen limitation on land and in the sea-How can it occur. Biogeochemistry 13, 87-115. 
Wilkerson, F. P. \& Dugdale, R. C. 1987 Effects of El Nino on new, regenerated, and total production in eastern boundary upwelling systems. Fournal of Geophysical Research 92, 14 347-14 353.

Wong, G. T. F., Pai, S. C., Liu, K. K., Liu, C. T. \& Chen, C. T. A. 1991 Variability of the chemical hydrography at the frontal region between the East China Sea and the Kuroshio northeast of Taiwan. Estuarine, Coastal and Shelf Science 33, 105120.

Zhang, J. 1996 Nutrient elements in large Chinese estuaries. Continental Shelf Research 16, 1023-1045. 